\title{
Daily food intake and digestibility in rats
}

\author{
BY T. LARSEN, KARIN ØSTERGARD, INGE HANSEN, \\ K. E. BACH KNUDSEN AND B. O. EGGUM* \\ National Institute of Animal Science, Animal Physiology and Biochemistry, \\ Foulum, P.O. Box 39, 8830 Tjele, Denmark
}

(Received 17 July 1990-Accepted 16 August 1990)

\begin{abstract}
The present work with growing rats was undertaken to study the effect of daily food intake (DFI) on true protein digestibility (TD), and apparent digestibility of dry matter (DM), energy (DE), starch, soluble dietary fibre (SDF) and insoluble dietary fibre (IDF). The design involved two different dietary combinations, barley + rapeseed meal (diet 1) and oats + wheat bran (diet 2). A slight but significantly negative relationship was seen between DFI and TD on diet 1 while no such relationship was found on diet 2. Although significant, DFI influenced DM digestibility of both diets only slightly. A similar situation could also be seen for the effect of DFI on DE. The digestibility of starch was significantly affected by DFI on both diets even though the lowest values were as high as 0.994. SDF digestibility (fermentability) was not influenced by DFI when the rats were given diet 1 , while there was a significant negative effect of DFI on digestibility of SDF when diet 2 was given. The digestibility (fermentability) of IDF was not affected by DFI on either of the two diets. The results confirm the existence of a weak negative relationship between DFI and digestibility of a range of nutrients although the effect seems to be only marginal and of no importance under practical feeding conditions.
\end{abstract}

Feeding level: Digestibility: Rat

In most digestibility trials food is offered at a lower feeding level than the eating ability of the experimental animals. This widespread practice is adopted in order to minimize feed residues, thus simplifying the interpretation of the experimental data. Under practical feeding conditions, however, most animals are fed ad lib. The question therefore arises whether the digestibility values determined under restricted feeding conditions will have general validity irrespective of feeding levels. A further question is how feeding levels affect the digestibility of various nutrients and whether the feeding level affects the fermentability of material entering the hind-gut. In other words, do animals have upper limits for the degree of fermentation/degradation of dietary fibres in the caecum-colon?

In ruminant nutrition it has consistently been shown that feeding level affects the digestibility coefficients negatively (Blaxter, 1967). In simple-stomached animals, however, little work has been done to illuminate the relationship between digestibility and food intake, and the work that has been done does not provide consistent conclusions. Cunningham et al. (1962) and Roth \& Kirchgessner (1984) found a significantly negative relationship between the digestibility of the various feed components and feeding level in their work with pigs. Just et al. (1983), however, in work with growing pigs, could not show any strict negative relationship between digestibility and feeding level.

In pigs fitted with ileo-caecal re-entrant cannulas, Sauer et al. (1982) found no effect of level of feed intake on the ileal digestibilities of crude protein and amino acids. In studies by Haydon et al. (1984) with pigs fitted with a simple T-cannula, it was demonstrated that

\footnotetext{
* For reprints.
} 
neither feeding method nor level greatly affected amino acid digestibilities but values tended to decrease as feeding level decreased. Nyman \& Asp (1985) showed in experiments with rats that the digestibility of fibre was independent of the dietary fibre level. The same workers also demonstrated that a $4 \mathrm{~d}$ adaptation to a diet was adequate when evaluating the fermentability of dietary fibre in rats. In more recent work Nyman et al. (1986) found a good correlation between the faecal bulking capacities in man and rat $(r 0.97)$, and it was concluded that the rat experimental model is useful for the prediction of fermentative breakdown and bulking capacity of dietary fibre in man.

The inconsistency in the literature cited above regarding the relationship between digestibility and feeding level led to the present work which was performed with rats. The rat was used as a model, based on the general agreement between digestibility coefficients obtained in rats and other simple-stomached animals (Eggum \& Beames, 1986). Two diets were prepared from rapeseed meal + barley (diet 1 ) and oats + wheat bran (diet 2), and fed to rats at ten different dry matter (DM) levels from $5 \mathrm{~g} / \mathrm{d}$ to $14 \mathrm{~g} / \mathrm{d}$. The two diets were chosen to provide different levels of protein and dietary fibres (DF). These diets also provided fibres with different solubility properties as this is believed to influence fermentability in the hind-gut considerably (Bach Knudsen et al. 1987a).

\section{EXPERIMENTAL}

\section{Diets}

The design involved two diets each provided at ten different levels. Diet 1 was composed of barley and rapeseed meal ( $1: 1, \mathrm{w} / \mathrm{w}$ on a DM basis) while diet 2 was composed of oats and wheat bran ( $1: 1, \mathrm{w} / \mathrm{w}$ on a DM basis). Each diet contained the same level of minerals $(40 \mathrm{~g} / \mathrm{kg} \mathrm{DM})$ and vitamins $(16 \mathrm{~g} / \mathrm{kg} \mathrm{DM})$ of a composition previously described by Eggum (1973). The dietary and chemical composition of the two diets is shown in Table 1.

\section{Animals and feeding}

The general experimental procedure has been described by Eggum (1973). Groups of five Wistar male rats weighing approximately $70 \mathrm{~g}$ were used, with a preliminary period of $6 \mathrm{~d}$ and a balance period of $5 \mathrm{~d}$. Each diet was given at ten different levels with increasing amounts from 5 to $14 \mathrm{~g} \mathrm{DM} /$ rat per d. Before the experiment started the animals were given a stock diet containing $25.7 \mathrm{~g}$ soluble dietary fibre (SDF) and $171.8 \mathrm{~g}$ insoluble dietary fibre (IDF) $/ \mathrm{kg}$ DM.

Digestibilities of protein, DM, energy (DE), starch, SDF and IDF were measured.

\section{Chemical analyses}

DM and crude protein (nitrogen $\times 6.25$ ) were determined by standard methods (Association of Official Analytical Chemists, 1975). The starch method involved gelatinization and hydrolysis of starch to oligosaccharides with a thermostable $\alpha$-amylase (Termamyl), further degradation to glucose monomers with amyloglucosidase and quantification with a glucose oxidase $(E C 1.1 .3 .4)$ reagent according to the method described by Bach Knudsen et al. (1987b).

Total dietary fibre (TDF) content was assayed by a gravimetric method based on enzymic digestion of starch and proteins as described by Asp et al. (1983). According to this method, TDF was divided into water-soluble (SDF) and water-insoluble (IDF) components.

Energy was determined by bomb calorimetry using an IKA-C 400 calorimeter (Janke \& Kunkel, GmbH, Staufen, West Germany). 
Table 1. Composition and major chemical constituents of the two experimental diets $(\mathrm{g} / \mathrm{kg}$ dry matter $(D M))$

\begin{tabular}{lrr}
\hline & Diet I & Diet 2 \\
\hline Barley & 472 & - \\
Rapeseed meal & 472 & - \\
Oats & - & 472 \\
Wheat bran & 40 & 40 \\
Mineral mixture* & 16 & 16 \\
Vitamin mixture* & $226 \cdot 3$ & $146 \cdot 7$ \\
Crude protein (nitrogen $\times 6 \cdot 25)$ & $297 \cdot 4$ & $342 \cdot 8$ \\
Starch & $52 \cdot 2$ & $49 \cdot 1$ \\
Soluble dietary fibre & $208 \cdot 9$ & 324.5 \\
Insoluble dietary fibre & $261 \cdot 1$ & $373 \cdot 6$ \\
Total dietary fibre & $19 \cdot 3$ & $19 \cdot 3$ \\
Energy (MJ/kg DM) & & \\
\hline \hline
\end{tabular}

* Composition according to Eggum (1973).

Statistical analysis

The results were subjected to two-way analysis of variance (ANOVA). Differences between groups were identified by the honestly significant difference (HSD; Tukey's test) (SAS, 1985). Regression analyses were performed on treatment means.

\section{RESULTS}

Digestibility measurements

Diet 1. Results for the digestibility measurements of protein (TD), DM, energy (DE), starch, SDF and IDF are presented in Table 2. The response of the digestibility measurements to daily food intake is described in regression equations presented in Table 3 .

TD was very similar at all feeding levels, with the highest value of $0 \cdot 844$ when the rats were given 5 or $8 \mathrm{~g} \mathrm{DM} / \mathrm{d}$. However, the $R^{2}$ value of 0.273 between TD and daily food intake was significant $(P<0.01)$.

The digestibility of DM varied from 0.743 to 0.760 with the lowest values at the highest daily food intakes $(P<0 \cdot 01)$. The statistical relationship between DM digestibility and daily food intake is described in Table 3.

DE varied from 0.746 to 0.766 with a significant $(P<0.01)$ negative relationship to daily food intake (Table 3).

Starch was highly digestible, with all values above 0.990 . However, there was a slight tendency for a negative relationship between digestible starch and daily food intake, with a significantly $(P<0.05)$ lower value at a food intake of $13 \mathrm{~g} / \mathrm{d}$.

The digestibility of SDF was relatively high $(>0.852)$ at all feeding levels with no significant $(P>0.05)$ relationship between digestibility of SDF and daily food intake.

The digestibility of IDF was low with the highest value of 0.405 . No statistically significant $(P>0.05)$ relationship between daily food intake and digestibility of IDF was seen (Table 3 ).

Diet 2. Results for the digestibility measurements of protein (TD), DM, energy (DE), starch, SDF and IDF are presented in Table 4. The response of the digestibility measurements to daily food intake is described in regression equations presented in Table 5 . 
Table 2. The effect of different feeding levels on digestibility in rats of crude protein, dry matter, energy, starch, soluble dietary fibre and insoluble dietary fibre, when given a mixture of barley and rapeseed meal $(1: 1, w / w$, dry matter basis) (diet 1 )

\begin{tabular}{|c|c|c|c|c|c|c|}
\hline $\begin{array}{l}\text { Daily food intake } \\
\text { (g dry matter/d)... }\end{array}$ & 5 & 6 & 7 & 8 & 9 & SEM \\
\hline $\begin{array}{l}\text { Crude protein } \\
\text { (nitrogen } \times 6.25 \text { ) }\end{array}$ & $0 \cdot 844^{\mathrm{a}}$ & $0.841^{\text {ab }}$ & $0.834^{\mathrm{ab}}$ & $0 \cdot 844^{\mathrm{a}}$ & $0 \cdot 843^{\mathrm{a}}$ & 0.012 \\
\hline Dry matter & $0.759^{\mathrm{a}}$ & $0 \cdot 760^{\mathrm{a}}$ & $0.760^{\mathrm{a}}$ & $0 \cdot 756^{\mathrm{a}}$ & $0 \cdot 760^{\mathrm{a}}$ & 0.011 \\
\hline Energy & $0 \cdot 763^{a}$ & $0.760^{\mathrm{a}}$ & $0 \cdot 760^{\mathrm{a}}$ & $0.764^{\mathrm{a}}$ & $0.766^{a}$ & 0.013 \\
\hline Starch & $0.997^{\mathrm{a}}$ & $0.997^{a}$ & $0.996^{\mathrm{ab}}$ & $0.996^{\mathrm{ab}}$ & $0.996^{\mathrm{ab}}$ & 0.001 \\
\hline Soluble dietary fibre & $0.852^{\mathrm{a}}$ & $0.857^{a}$ & $0.868^{a}$ & $0.874^{a}$ & $0.861^{\mathrm{a}}$ & 0.018 \\
\hline Insoluble dietary fibre & $0 \cdot 389^{\mathrm{a}}$ & $0 \cdot 396^{\mathrm{a}}$ & $0 \cdot 382^{\mathrm{a}}$ & $0 \cdot 371^{a}$ & $0.405^{\mathrm{a}}$ & 0.019 \\
\hline $\begin{array}{l}\text { Daily food intake } \\
\text { (g dry matter/d)... }\end{array}$ & 10 & 11 & 12 & 13 & $>13$ & SEM \\
\hline $\begin{array}{l}\text { Crude protein } \\
\text { (nitrogen } \times 6.25 \text { ) }\end{array}$ & $0.837^{u b}$ & $0 \cdot 834^{\mathrm{al}}$ & $0 \cdot 820^{a b}$ & $0.832^{a b}$ & $0 \cdot 818^{h}$ & $0 \cdot 012$ \\
\hline Dry matter & $0.757^{\mathrm{a}}$ & $0.752^{\mathrm{a}}$ & $0.750^{\mathrm{a}}$ & $0.749^{\mathrm{a}}$ & $0.743^{\mathrm{a}}$ & 0.011 \\
\hline Energy & $0.763^{\mathrm{a}}$ & $0 \cdot 752^{\mathrm{a}}$ & $0.747^{\mathrm{a}}$ & $0.746^{\mathrm{a}}$ & $0.747^{\mathrm{a}}$ & 0.013 \\
\hline Starch & $0.995^{\text {abl }}$ & $0.996^{\text {aib }}$ & $0.995^{a b}$ & $0.994^{b}$ & $0.995^{\mathrm{ab}}$ & 0.001 \\
\hline Soluble dietary fibre & $0.861^{\mathrm{a}}$ & $0.866^{\mathrm{a}}$ & $0 \cdot 860^{\mathrm{L}}$ & $0.870^{\mathrm{a}}$ & $0.876^{\mathrm{a}}$ & 0.018 \\
\hline Insoluble dietary fibre & $0 \cdot 381^{\mathrm{a}}$ & $0 \cdot 376^{\mathrm{a}}$ & $0.389^{a}$ & $0.391^{\mathrm{a}}$ & $0.382^{\mathrm{a}}$ & 0.019 \\
\hline
\end{tabular}

a-b Within horizontal rows, mean values with unlike superscript letters were significantly different : $P<0.05$.

Table 3. Regression equations between digestibility and daily food intake (DFI) (diet I)

\begin{tabular}{ll} 
Protein $=$ & $0.859-2.53 \times 10^{-3} \times \mathrm{DFI}, R^{2} 0.273, P<0.01$ \\
Dry matter $=$ & $0 \cdot 772-1 \cdot 75 \times 10^{-3} \times \mathrm{DFI}, R^{2} 0 \cdot 189, P<0.01$ \\
Energy $=$ & $0 \cdot 777-2 \cdot 12 \times 10^{-3} \times \mathrm{DFI}, R^{2} 0 \cdot 191, P<0.01$ \\
Starch $=$ & $1 \cdot 00-0.287 \times 10^{-3} \times \mathrm{DFI}, R^{2} 0.351, P<0.05$ \\
Soluble dietary fibre $=$ & $0.847+1.86 \times 10^{-3} \times \mathrm{DFI}, R^{2} 0.080, P>0.05$ \\
Insoluble dietary fibre $=$ & $0.390-4.31 \times 10^{-4} \times \mathrm{DFI}, R^{2} 0.003, P>0.05$ \\
\hline
\end{tabular}

TD was very similar at all feeding levels, with the highest value of $0 \cdot 799$. There were no significant differences $(P>0.05)$ between groups and no significant $(P>0.05)$ relationship between TD and daily food intake (Table 5).

DM digestibility was low in the range $0.622-0.646$ with no significant differences between groups. It appears from the equation in Table 5 that there was a significant $(P<0.01)$ negative relationship between DM digestibility and daily food intake.

Energy digestibility like DM digestibility was low with no significant $(P>0.05)$ differences between groups and there was no significant relationship between energy digestibility and daily food intake (Table 5).

The digestibility of starch was almost complete but the groups differed significantly $(P<0.05)$, with the lowest values at the highest daily food intakes (Table 4$)$. The relationship between digestibility of starch and daily food intake is expressed by an equation in Table 5 .

The digestibility of SDF varied with significantly $(P<0.05)$ lower values at the highest daily food intakes. The relationship is seen in Table 5.

The digestibility of IDF was low, in the range $0 \cdot 223-0 \cdot 249$, with no significant $(P>0 \cdot 05)$ differences between the ten daily food intakes. 
Table 4. The effect of different feeding levels on digestibility in rats of crude protein, dry matter, energy, starch, soluble dietary fibre and insoluble dietary fibre, when given a mixture of oats and wheat bran $(1: 1, w / w$, dry matter basis) (diet 2)

\begin{tabular}{|c|c|c|c|c|c|c|}
\hline $\begin{array}{l}\text { Daily food intake } \\
\text { (g dry matter/d) ... }\end{array}$ & 5 & 6 & 7 & 8 & 9 & SEM \\
\hline $\begin{array}{l}\text { Crude protein } \\
\text { (nitrogen } \times 6.25 \text { ) }\end{array}$ & $0.780^{\mathrm{a}}$ & $0.798^{4}$ & $0.781^{\mathrm{a}}$ & $0.779^{a}$ & $0 \cdot 796^{\mathrm{a}}$ & 0.014 \\
\hline Dry matter & $0.633^{a}$ & $0.646^{\mathfrak{a}}$ & $0.637^{i}$ & $0 \cdot 630^{\mathrm{a}}$ & $0.639^{\mathrm{a}}$ & 0.013 \\
\hline Energy & $0.643^{\mathrm{a}}$ & $0.644^{\mathrm{a}}$ & $0.635^{\mathrm{a}}$ & $0.632^{\mathrm{a}}$ & $0.646^{\mathrm{a}}$ & 0.008 \\
\hline Starch & $0.997^{\mathrm{a}}$ & $0.997^{\mathrm{a}}$ & $0.997^{\mathrm{a}}$ & $0.997^{\mathrm{a}}$ & $0.997^{a}$ & 0.001 \\
\hline Soluble dietary fibre & $0.755^{\mathrm{u}}$ & $0 \cdot 750^{\mathrm{ab}}$ & $0.767^{a}$ & $0.766^{\mathrm{a}}$ & $0.765^{\mathrm{a}}$ & 0.024 \\
\hline Insoluble dietary fibre & $0 \cdot 247^{\mathrm{a}}$ & $0 \cdot 249^{\mathrm{a}}$ & $0 \cdot 249^{a}$ & $0 \cdot 223^{x}$ & $0 \cdot 234^{\mathrm{a}}$ & 0.021 \\
\hline $\begin{array}{l}\text { Daily food intake } \\
\text { (g dry matter/d) ... }\end{array}$ & 10 & 11 & 12 & 13 & $>13$ & SEM \\
\hline $\begin{array}{l}\text { Crude protein } \\
\text { (nitrogen } \times 6.25 \text { ) }\end{array}$ & $0.795^{\mathrm{a}}$ & $0.792^{\mathrm{a}}$ & $0.799^{\mathrm{a}}$ & $0.794^{a}$ & $0.774^{\mathrm{a}}$ & 0.014 \\
\hline Dry matter & $0 \cdot 634^{\mathrm{a}}$ & $0.627^{\mathrm{a}}$ & $0.622^{u}$ & $0 \cdot 626^{a}$ & $0.626^{\mathrm{a}}$ & $0-013$ \\
\hline Energy & $0 \cdot 648^{u}$ & $0.63 I^{\mathrm{a}}$ & $0.636^{\mathrm{a}}$ & $0.632^{\mathrm{a}}$ & $0.638^{\mathrm{a}}$ & 0.008 \\
\hline Starch & $0.997^{\mathrm{a}}$ & $0.996^{\mathrm{ab}}$ & $0.995^{\text {be }}$ & $0.994^{\mathrm{c}}$ & $0.993^{\circ}$ & 0.001 \\
\hline Soluble dietary fibre & $0.762^{\mathrm{a}}$ & $0.713^{b}$ & $0.722^{\mathrm{ab}}$ & $0.712^{\mathrm{b}}$ & $0.703^{b}$ & 0.024 \\
\hline Insoluble dietary fibre & $0 \cdot 244^{\mathrm{a}}$ & $0.236^{\mathrm{a}}$ & $0.236^{a}$ & $0.229^{\mathrm{a}}$ & $0 \cdot 243^{a}$ & 0.021 \\
\hline
\end{tabular}

ac Within horizontal rows, mean values with unlike superscript letters were significantly different: $P<0 \cdot 05$.

Table 5. Regression equations between digestibility and daily food intake (DFI) (diet 2)

$\begin{array}{ll}\text { Protein }= & 0.785+0.351 \times 10^{-3} \times \mathrm{DFI}, R^{2} 0.005, P>0.05 \\ \text { Dry matter }= & 0.649-1.78 \times 10^{-3} \times \mathrm{DFI}, R^{2} 0.146, P<0.01 \\ \text { Energy }= & 0.645-7.32 \times 10^{-4} \times \mathrm{DFI}, R^{2} 0.038, P>0.05 \\ \text { Starch }= & 100-0-0.461 \times 10^{-3} \times \mathrm{DFI}, R^{2} 0.545, P<0.001 \\ \text { Solublc dietary fibre }= & 0.805-6.73 \times 10^{-3} \times \mathrm{DFI}, R^{2} 0.355, P<0.001 \\ \text { Insoluble dietary fibre }= & 0.250-1.12 \times 10^{-3} \times \mathrm{DFI}, R^{2} 0.026, P>0.05\end{array}$

\section{DISCUSSION}

The two diets of barley + rapeseed meal (diet 1) and oats + wheat bran (diet 2) differed considerably with regard to protein, starch, and soluble and insoluble DF (Table 1). It was thus possible to study not only the effect of daily food intake on overall digestibility of macronutricnts, but also the digestibilities of nutrients chiefly absorbed in the small intestine $v$. DF polysaccharides primarily degraded in the large intestine (Nyman et al. 1985).

The present study demonstrates the existence of a slight but statistically significant relationship between daily food intake and digestibility of most of the measured components. When significant the relationship was negative, in agreement with the work of Cunningham et al. (1962) and Roth \& Kirchgessner (1984) working with pigs. However, the influence of daily food intake was much less in the present study compared with the works cited above. Roth \& Kirchgessner (1984) found that an increase in feeding level to three times maintenance levels in piglets reduced the digestibility of energy, crude protein and crude fibre significantly by 3,6 and $8 \%$ respectively. We could not demonstrate the same effect of daily food intake as the differences between the highest and lowest values were at most 4 to $5 \%$ and in most cases much lower or there were no differences at all. The 
results in the present study are thus more in agreement with the work of Just et al. (1983) and Haydon et al. (1984) who could not find any strict negative relationship between digestibility and daily food intake in work with pigs.

In spite of the influence of daily food intake on digestibility being low for both diets, dietary components could be differently affected. The reason for this is probably the differences in dietary composition of the two diets. One of concern is whether the degradation of DF would be more sensitive to daily food intake than fractions like protein and starch which are absorbed chiefly in the small intestine and are thus sensitive to food intake. A factor to consider is the influence of daily food intake on transit time (Raczynski et al. 1982; Wrick et al. 1983). These authors demonstrated that food intake as well as the fibre concentration in the diets influenced transit time. Transit time affects the time available for microbial fermentation in the hind-gut. Diet 2 (oats + wheat bran) contained $374 \mathrm{~g} \mathrm{DF} / \mathrm{kg} \mathrm{DM} \mathrm{v.} 261 \mathrm{~g}$ in diet 1 (barley + rapeseed meal). Digestibility of SDF was also much more affected by daily food intake when diet 2 was given compared with the situation for diet 1 . However, DE of diet 2 was not influenced by daily food intake while it was for diet 1 .

In this context it should be stressed that the digestibility values in general were much higher on diet 1 than on diet 2. This was especially the case for IDF, demonstrating a higher resistance to microbial degradation of the fibre in diet 2 than in diet 1 . This is due to differences in the chemical and structural composition of DF in the two diets which again can affect transit time and thus degradation (Van Soest et al. 1982).

The much lower TD values obtained on diet 2 are probably due to a relatively high proportion of $\mathrm{N}$ associated with the fibres in wheat bran (Donangelo \& Eggum, 1985) and relatively more $\mathrm{N}$ synthesized into microbial protein (Beames \& Eggum, 1981).

\section{CONCLUSION}

The present study with rats showed that daily food intake did affect digestibility of most dietary components. However, the major food components such as starch and protein (and consequently DM and energy) were only marginally influenced by food intake, in most cases less than $2 \%$. Based on the presents results, digestibility coefficients obtained at restricted levels of feeding can also be applied to simple-stomached animals fed $a d$ lib.

\section{REFERENCES}

Asp, N.-G., Johansson, C. G., Hallmer, H. \& Siljestrøm, M. (1983). A rapid enzymatic method for assay of insoluble and soluble dietary fibre. Journal of Agriculture and Food Chemistry 31, 476-482.

Association of Official Analytical Chemists (1975). Official Methods of Analysis. 11 th ed. Washington, DC: Association of Official Analytical Chemists.

Bach Knudsen, K. E., Åman, P. \& Eggum, B. O. (1987a). Nutritive value of Danish-grown barley varieties. I. Carbohydrates and other major constituents. Journal of Cereal Science 6, 173-186.

Bach Knudsen, K. E., Eggum, B. O. \& Jacobsen, I. (1987 b). Nutritive value of Danish-grown barley varieties. II. Effects of carbohydrate composition on digestibility of energy and protein. Journal of Cereal Science 6, 187-195.

Beames, R. M. \& Eggum, B. O. (1981). The effect of type and level of protein, fibre and starch on nitrogen excretion patterns in rats. British Journal of Nutrition 46, 301-313.

Blaxter, K. L. (1967). The Energy Metabolism of Ruminants, 2nd ed. London: Hutchinson.

Cunningham, H. M., Friend, D. W. \& Nicholson, J. W. G, (1962). The effect of age, body weight, feed intake and adaptability of pigs on the digestibility, and nutritive value of cellulose. Canadian Joumal of Animal Science $\mathbf{4 2}$ 167-175.

Donangelo, C. M. \& Eggum, B. O. (1985). Comparative effects of wheat bran and barley husk on nutrient utilization in rats. 1. Protein and energy. British Journal of Nutrition 54, 741-751.

Eggum, B. O. (1973). A study of certain factors influencing protein utilization in rats and pigs. National Institute of Animal Science, Report no. 406, p. 173. Copenhagen.

Eggum, B. O. \& Beames, R. M. (1986). Use of laboratory animals as models for studies on nutrition of domestic animals. In Laboratory Animals, pp. 265-290. [E. J. Ruitenberg and P. W. J. Peters, editors]. Amsterdam: Elsevier Science Publishers B.V. 
Haydon, K. D., Knabe, D. A. \& Thanksley, T. D. Jr (1984). Effect of level of feed intake on nitrogen, amino acid and energy digestibilities measured at the end of the small intestine and over the total digestive tract. Journal of Animal Science 59, 717-724.

Just, A., Jørgensen, H. \& Fcrnandez, J. A. (1983). Maintenance requirement and the energy value of different diets for growth in pigs. Livestock Production Science 10, 487-506.

Nyman, M. \& Asp, N.-G. (1985). Dietary fibre fermentation in the rat intestinal tract: effect of adaptation period, protein and fibre levels, and particle size. British Journal of Nutrition 54, 635-643.

Nyman, M., Asp, N.-G., Cummings, J. \& Wiggins, H. (1986). Fermentation of dietary fibre in the intestinal tract: comparison between man and rat. British Journal of Nutrition 55, 487-496.

Nyman, M., Asp, N.-G., Pedersen, B. \& Eggum, B. O. (1985). Fermentation of dietary fibre in the intestinal tract of rats - a comparison of flours with different extraction rates from six cereals. Journal of Cereal Science $\mathbf{3}$, $207-219$

Raczynski, G., Eggum, B. O. \& Chwalibog, A. (1982). The effect of dietary composition on transit time in rats. Zeitschrift für Tierphysiologie, Tierernährung und Futtermittelkunde 47, 160-167.

Roth, F. X. \& Kirchgessner, M. (1984). Verdaulichkeit der Energie und Rohnährstoffe beim Schwein in Abhängigkeit von Fütterungsniveau und Lebengewicht. Zeitschrift für Tierphysiologie, Tierernährung und Futtermittelkunde 51, 79-87.

SAS (1985). User's Guide. Statistics. Gary, N.C.: Statistical Analysis System Institute, Inc.

Sauer, W. C., Just, A. \& Jørgensen, H. (1982). The effect of feed intake on ileal and fecal availabilities in pigs. Zeitschrift für Tierphysiologie, Tierernährung und Futtermittelkunde 48, 177-192.

Van Soest, P. J., Jeraci, J., Foose, T., Wrick, K. L. \& Ehler, F. (1982). Comparative fermentation of fibre in man and other animals. In Fibre in Human and Animal Nutrition, pp. 75-80 [G. Wallace and L. Bell, editors]. Queenstown: The Royal Society of New Zealand.

Wrick, K. L., Robertson, J. B., Van Soest, P. J., Lewis, B. A., Rivers, J. M., Roe, D. A. \& Hackler, L. R. (1983). The influence of dietary fibre source on human intestinal transit and stool output. Journal of Nutrition $\mathbf{1 1 3}$ 14641479. 